\title{
Relationship between body composition and physical capacities in junior soccer players
}

\section{Relação entre a composicão corporal e as capacidades físicas em jogadores de futebol de categorias de base}

\author{
Daniela Zanini ${ }^{1}$ \\ (D) https://orcid.org/0000-0002-6818-7508 \\ Augusto Kuipers ${ }^{1}$ \\ (D) https://orcid.org/0000-0003-1253-9014 \\ Indianara Vicini Somensi \\ (D) https://orcid.org/0000-0002-2868-0971 \\ Jonathan Filipe Pasqualotto 1 \\ (1) https://orcid.org/ 0000-0002-0469-4340 \\ Julia de Góis Quevedo \\ (D) https://orcid.org/0000-0002-6693-9075. \\ Jucielly Carla Te0 ${ }^{1}$ \\ (1) https://orcid.org/ 0000-0003-1151-2178 \\ Danielle Ledur Antes \\ (D) https://orcid.org/ 0000-0002-9611-519X
}

Abstract - The number of studies related to soccer has been growing exponentially in the last years because the modality is considered the most popular in the world. It is known that the development of some specific physical capacities, even in young individuals, is essential to high-level performance and these capacities might be related to anthropometrics variables. The purpose of this study was to verify the relationship between body composition and physical capacities in young soccer players. Study participants were athletes from junior categories (under-12 and under-13) belonging to the Soccer Association of Chapecó, Brazil.. Athletes were submitted to agility, (Illinois), vertical jump (Sargent Jump), aerobic condition (TCAR), flexibility and sit-and-reach (Wells Bench) tests, as well as anthropometric assessment. All procedures were performed at UNOESC campus, Chapecó. Statistical analysis consisted of the Spearman's Rô test, measuring the correlation among variables, additionally, significance level of $p<0.05$ was adopted. Results showed significantly correlation in agility $(p=0.000 ; \rho=0.530)$ and vertical jump tests $(p=0.003 ; \rho=-0.437)$ with body fat percentage. It was concluded that there is relationship between body fat percentage and agility and explosive power of lower limbs.

Key words: Adolescent; Body composition; Physical fitness; Soccer.

Resumo - O número de estudos relacionados ao futebol vem crescendo exponencialmente nos últimos anos, visto que a modalidade é considerada a mais popular do mundo. Sabe-se que o desenvolvimento de algumas capacidades físicas, ainda que em jovens, são imprescindíveis para a prática em alto nível e que estas podem estar relacionadas com variáveis antropométricas. Este estudo teve como objetivo verificar a relação entre a composição corporal e as capacidades físicas em jogadores de futebol de categorias de base. Os participantes foram atletas das categorias de base sub12 e sub13 da Associação Chapecoense de Futebol. Estes foram submetidos a testes físicos de agilidade (Illinois), impulsão vertical (Sargent Jump), aptidão aeróbia (TCAR), teste de flexibilidade de sentar e alcançar (Banco de Wells) e avaliação antropométrica. Todos os procedimentos foram realizados no Campus da UNOESC-Chapecó. A análise de dados baseou-se no teste de Rô de Spearman para a correlaçâo entre as variáveis, adotando nível de significância $p<0,05$. Os resultados demonstraram correlação significativa nos testes físicos de agilidade $(p=0,000 ; \rho=0,530)$ e impulsão vertical $(p=0,003 ; \rho=-0,437)$ com o percentual de gordura. Conclui-se que existe uma relação entre percentual de gordura corporal sobre as capacidades físicas agilidade e força explosiva de membros inferiores.

Palavras-chave: Adolescente; Aptidão física; Composição corporal; Futebol.
1 Universidade do Oeste de Santa Catarina. Chapecó, SC. Brasil.

Received: December 19, 2018 Accepted: August 30, 2019

How to cite this article Zanini D, Kuipers A, Somensi IV, Pasqualotto JF, Quevedo JG, Teo JC, Antes DL. Relationship between body composition and physical capacities in junior soccer players. Rev Bras Cineantropom Desempenho Hum 2020, 22:e60769. D0I: http://dx.doi.org/ 10.1590/1980-0037.2020v22e60769

Copyright: This work is licensed under a Creative Commons Attribution 4.0 International License. 


\section{INTRODUCTION}

Soccer is the most popular sport in the world ${ }^{1}$, being practiced by various age groups and both sexes. For this reason, several researchers have searched for knowledge in this modality ${ }^{2}$. Performance during a soccer match, both professional and amateur, depends on technical, biomechanical, tactical, psychological and physiological factors. These factors include the skills of a soccer player; however, mastering only one of them is not enough ${ }^{3}$.

During the game period, an athlete travels between 9 and $14 \mathrm{~km}$ and performs about 1330 activities ${ }^{4-7}$. Therefore, soccer is a sport that requires great aerobic needs, and the most decisive periods of the game depend on movements generated by anaerobic energy ${ }^{2,8}$.

About $96 \%$ of sprints made during a game are less than 30 meters and $49 \%$ of these sprints are over 10 meters; thus, performance above or below this distance is considered an indicator of athlete's power'. Due to the advantage of good motor power to generate force, several studies have focused on the evaluation of explosive power of lower limbs and agility $y^{10-13}$.

Another essential physical attribute in the performance of sports gestures is flexibility, which undergoes adaptations with the sport modality $^{14}$. Achieving the optimal flexibility level positively affects joint range, strength, and speed of movement during exercises, making them easier to be performed, decreasing total energy expenditure because the range of motion is efficient for the performance of specific gestures ${ }^{15-17}$.

There is evidence that physiological requirements may vary with age, height, body composition and body mass index among players ${ }^{18}$. However, the development of anthropometric and physiological characteristics necessary for a soccer match may not be fully developed in young soccer players, as experience is smaller and the training intensity is equally lower ${ }^{8}$.

The aim of this study was to verify the relationship between body composition and physical abilities of agility, explosive power of lower limbs and flexibility in young soccer players.

\section{METHOD}

\section{Participants}

Study participants were 44 male soccer athletes, belonging to the under-12 and under-13 categories of the Soccer Association of Chapecó, Brazil.

\section{Anthropometry and body composition}

Anthropometric measurements were obtained according to standards of the International Society for the Advancement of Kinanthropometry $\left(\mathrm{ISAK}^{\circledR}{ }^{\circledR}{ }^{19}\right.$. Height measurements were obtained using a wall metric scale with $0.01 \mathrm{~m}$ resolution and for body mass, Toledo ${ }^{\circledR}$ weighing scale with $50 \mathrm{~g}$ resolution was used.

Skinfolds collected were triceps, supraspinatus, subscapularis and medial leg, using a scientific Cescorf ${ }^{\circledR}$ adipometer with $0.01 \mathrm{~mm}$ resolution and body fat percentage (\% BF) was estimated from Slaughter's equation (1988). 


\section{Physical tests}

Illinois physical tests were used to measure agility ${ }^{20}$ and Sargent Jump ${ }^{21}$ to measure the explosive power of lower limbs.

To measure aerobic performance, the $\mathrm{TCAR}^{22}$ test was used, which consists of running guided by sound stimuli within a predetermined space.

In the flexibility evaluation, the sit-and-reach test was performed through Sanny ${ }^{\circledR}$ Wells bench ${ }^{23}$.

\section{Collection Procedures}

Tests were performed in two days. On the first day, anthropometric measurements were performed, and later, the following physical tests were applied: agility, flexibility, explosive power of lower limbs and after 48 hours, the aerobic fitness test was applied.

All tests were performed at the Western University Santa Catarina Chapecó facilities, including the kinanthropometry, weight training and soccer field laboratories.

\section{Data analysis process}

Descriptive data analysis was used by calculating the mean and standard deviation. Data normality was tested by the Shapiro-Wilk test. To test the relationship among variables, nonparametric correlation statistic was used by the Spearman's Rô test, adopting significance of $\mathrm{p}<0.05$. All tests were performed using the IBM-SPSS ${ }^{\circledR}$ version 21 statistics software.

\section{Research Ethics}

All participants received prior explanation of study procedures and signed the informed consent form and written assent form. The study followed standards of the National Research Ethics Commission (CONEP / UPE: 026146/2015). Procedures adhered to the guidelines of the Declaration of Helsinki, and were approved by the Research Ethics Committee of the Western University of Santa Catarina, CAAE 71079317.1.0000.5367, protocol No. 2.189.800.

\section{RESULTS}

Forty-four athletes from base categories of the Soccer Association of Chapecó, Brazil, with average age of $12.17 \pm 0.73$ years, average height of $152.95 \pm 9.37 \mathrm{~cm}$ and body mass of $42.53 \pm 9.29 \mathrm{~kg}$ were investigated. The mean values ( $\mathrm{m}$ and $\mathrm{sd}$ ) of characterization variables and tests used are presented in table 1 .

Table 2 shows the correlation between body fat percentage (\% BF) and the variables agility, aerobic capacity, explosive power of lower limbs and flexibility, which showed significance only in agility $(\rho=0.53 ; p=0.00)$ and explosive power of lower limbs $(\rho=-0.44 ; p=0.003)$. 
Table 1. Characterization of soccer athletes from base categories of the Soccer Association of Chapecó, Brazil.

\begin{tabular}{lccc}
\hline Variables & N & mean & Standard deviation \\
\hline Age (years) & 44 & 12.17 & 0.73 \\
Height $(\mathrm{cm})$ & 44 & 152.95 & 9.37 \\
Body mass $(\mathrm{kg})$ & 44 & 42.53 & 9.29 \\
Body fat (\%) & 44 & 13.67 & 5.00 \\
Agility (s) & 44 & 18.14 & 0.82 \\
Aerobic capacity (km/h) & $23^{*}$ & 12.65 & 0.78 \\
Explosive power of lower limbs (distance in $\mathrm{cm})$ & 44 & 37.60 & 5.30 \\
Flexibility (cm) & 44 & 27.20 & 4.68 \\
\hline
\end{tabular}

Note * There was sample loss, only under-12 athletes performed the test.

Table 2. Spearman correlation between \%BF and independent variables.

\begin{tabular}{lccc}
\hline \multirow{2}{*}{ Variables } & \multicolumn{3}{c}{$\% \mathrm{BF}$} \\
\cline { 2 - 4 } & $\mathrm{N}$ & $\rho$ & $\mathrm{p}$-value \\
\hline Agility (sec.) & 44 & 053 & $<0.01^{*}$ \\
Aerobic capacity $(\mathrm{km} / \mathrm{h})$ & 23 & -041 & 0.06 \\
Explosive power of lower limbs (distance in $\mathrm{cm})$ & 44 & -044 & $<0.01^{*}$ \\
Flexibility $(\mathrm{cm})$ & 44 & -027 & 0.82 \\
\hline
\end{tabular}

Note $\%$ BF: body fat percentage of * significant difference at level of $\rho<0.05$.

\section{DISCUSSION}

The aim of this study was to verify the relationship between body composition and physical abilities of agility, explosive power of lower limbs and flexibility in young soccer players.

In a study by Benounis et $\mathrm{al}^{2}{ }^{26}$, evaluating 42 soccer players with mean age of 14.8 (SD 0.4) years, results similar to those observed in the present study were found. The Illinois test obtained average of 17.7 (dp 0.62 ) seconds, while for explosive power of lower limbs, the average was 40.13 (dp 4.89) $\mathrm{cm}$. This demonstrates the good performance of athletes evaluated in the present study, since the mean age of this group is lower.

Another study conducted with several categories of elite soccer players, under-13 category showed body mass of 39.3 (sd 5.1) kg and height of $150(\mathrm{sd} 6.0) \mathrm{cm}$, characterization data very similar to those of the present investigation ${ }^{24}$. Regarding body fat percentage, Le Gall et al..$^{27}$ found for elite under-14 players of the Clairefontaine National Soccer Institute, the value of 11.9 (sd 1.42)\%, lower than that found in the present study.

The results of this research indicated a relationship between fat percentage and agility, demonstrating that the higher the fat percentage, the lower the agility and the higher the explosive power of lower limbs. Similar results were found in the study by Keogh et al. ${ }^{28}$, who found difference in mean agility and explosive power of lower limbs of two different groups of young hockey athletes.

In a study by Dellagrana et al. ${ }^{29}$ with handball athletes $(n=47)$ aged 12-17 years, an inverse relationship was found between fat percentage and 
explosive power of lower limbs $(r=-0.42)$, measured by the horizontal impulse test, which presented values similar to those of the present study $(\rho=-0.44)$, although the physical valence was measured by a different test.

In the same study, agility measured by the Shuttle-run test was also related to athletes' fat percentage, this time, with positive direction $(\mathrm{r}=$ 0.61). Despite the use of a different test to measure physical capacity, results are similar to those of this research $(\rho=0.53)$.

Soccer requires the athlete to have morphological qualities that provide greater ability to respond to demands of game situations, so anthropometric profile can be considered an indicator of success in sports performance, combined with agility, an important physical ability to react to different stimuli quickly and efficiently.

In addition, association between fat percentage and power of lower limbs was also observed, and athletes with higher fat percentage had lower explosive power of lower limbs.

Body composition is an important aspect for the physical fitness level of amateur and professional athletes of any type, since excess body fat may decrease performance ${ }^{25}$. The $\% \mathrm{BF}$ values found were slightly above those accepted for high-performance athletes, which leads us to believe that if the physical potential is correctly worked, these athletes will have a considerable increase in performance.

\section{CONCLUSION}

The present study analyzed the relationship between body composition and physical abilities of agility, explosive power of lower limbs and flexibility in young soccer players. The results indicate the relationship between body fat percentage and physical abilities agility and explosive power of lower limbs.

Although age and maturation of athletes of this age group are susceptible to rapid changes due to development and physical growth, the control of fat percentage must be continuously performed because, according to this study, it has direct relationship with physical performance.

Therefore, the coaching staff should take current results into account and should not discriminate younger or late maturing players who may develop their skills later.

It is also noteworthy that, given the small sample size, there are limitations regarding associations made, and further studies should be carried out using larger samples, as well as possible comparisons with athletes from other categories, modalities and regions.

\section{COMPLIANCE WITH ETHICAL STANDARDS}

\section{Funding}

This research did not receive any specific grant from funding agencies in the public, commercial, or non-profit sectors. This study was funded by the authors. 


\section{Ethical approvalw}

Ethical approval was obtained from the local Human Research Ethics Committee - Universidade do Oeste de Santa Catarina (protocol no. CAAE 71079317.1.0000.5367), and it was written in accordance with the standards set by the Declaration of Helsinki.

\section{Conflict of interest statement}

The authors have no conflict of interests to declare.

\section{Author Contributions}

Conceived and designed the experiments: DZ, DLA and JCT. Performed the experiments: DZ, DLA, JCT, AK, IVS, JFP and JQG. Analyzed data: DZ and DLA. Contributed with reagents/materials/analysis tools: DZ, DLA, JCT, AK, IVS, JFP and JQG. Wrote the paper: DZ, DLA, JCT, AK, IVS, JFP and JQG.

\section{REFERENCES}

1. Grygorowicz M, Piontek T, Dudzinski W. Evaluation of functional limitations in female soccer players and their relationship with sports level-a cross sectional study. PloS one 2013; 8(6):66871.

2. Ramírez-Campillo R, Burgos CH, Henríquez-Olguín C, Andrade DC, Martínez C, Álvarez C, et al. Effect of unilateral, bilateral, and combined plyometric training on explosive and endurance performance of young soccer players. J Strength Cond Res 2015; 29(5):1317-1328.

3. Stølen T, Chamari K, Castagna C, Wisløff U. Physiology of soccer. Sports Med 2005 35(6):501-536.

4. Bangsbo J, Mohr M, Krustrup P. Physical and metabolic demands of training and match-play in the elite football player. J Sports Sci 2006; 24(07):665-674

5. Barros RM, Misuta MS, Menezes RP, Figueroa PJ, Moura FA, Cunha SA, et al. Analysis of the distances covered by first division Brazilian soccer players obtained with an automatic tracking method. J Sports Sci Med 2007; 6(2): 233.

6. Di Salvo V, Baron R, Tschan H, Montero FC, Bachl N, Pigozzi F. Performance characteristics according to playing position in elite soccer. Int J Sports Med 2007;28(03):222-227.

7. Sarmento H, Marcelino R, Anguera MT, Campaniço J, Matos N, Leitão JC. Match analysis in football: a systematic review. J Sports Sci 2014; 32(20)1831-1843.

8. Deprez D, Fransen J, Boone J, Lenoir M, Philippaerts R, Vaeyens, R. Characteristics of high-level youth soccer players: variation by playing position. J Sports Sci 2015;33(3): 243-254.

9. De Villarreal ES, Suarez-Arrones L, Requena B, Haff GG, Ferrete C. Effects of plyometric and sprint training on physical and technical skill performance in adolescent soccer players. J Strength Cond Res 2015; 29(7):1894-1903.

10. Delecluse, C. Influence of strength training on sprint running performance. Sports Med 1997; 24(3);147-156.

11. Rimmer E, Sleivert G. Effects of a plyometric intervention program on sprint performance. J Strength Cond Res 2000; 14(3):295-301.

12. De Villarreal ES, González-Badillo JJ, Izquierdo M. Low and moderate plyometric training frequency produces greater jumping and sprinting gains compared with high frequency. J Strength Cond Res 2008;22(3):715-725.

13. De Villarreal ES, Requena B, Izquierdo M, Gonzalez-Badillo JJ. Enhancing sprint and strength performance: combined versus maximal power, traditional heavy-resistance and plyometric training. J Sports Sci Med 2013;16(2):146-150. 
14. Sena DA, Ferreira FM, Melo RHG, Taciro C, Carregaro RL, Oliveira Júnior SA. Análise da flexibilidade segmentar e prevalência de lesões no futebol segundo faixa etária. Fisiot Pesqu 2013; 20(4):343-348.

15. Veiga PHA, Daher CRM, Morais MFF. Alterações posturais e flexibilidade da cadeia posterior nas lesões em atletas de futebol de campo. Rev Bras Ciênc Esporte 2011; 33(1):235-248

16. Bertolla F, Baroni BM, Leal Junior EC, Oltramari JD. Efeito de um programa de treinamento utilizando o método Pilates ${ }^{\circledR}$ na flexibilidade de atletas juvenis de futsal. Rev Bras Med Esporte 2007; 13(4):222-226.

17. De Moraes MA, Spinoso DH, Navega MT. Effectiveness of performing hamstring stretches under physiotherapeutic supervision. ConScientiae Saúde 2015; 14(2):298.

18. Bloomfield J, Polman R, O'donoghue P. Physical demands of different positions in FA Premier League soccer. J Sports Sci Med 2007; 6(1):63.

19. Marfell-Jones M, Stewart A, Ridder J. International Society for the Advancement of Kinanthropometry. International standards for anthropometric assessment. Potchefstroom (South Africa): International Society for the Advancement of Kinanthropometry. Routledge, 2006.

20. Roozen, M. Illinois agility test. NSCA's Perform Train J 2004; 3(5)5-6.

21. De Salles P, Vasconcellos F, De salles G, Fonseca R, Dantas, E. Validity and reproducibility of the sargent jump test in the assessment of explosive strength in soccer players. J Hum Kinet 2012; (33):115-121.

22. Carminatti LJ, Lima-Silva AE, De-Oliveira FR. Aptidão Aeróbia em esportes intermitentes: evidências de validade de construto e resultados em teste incremental com pausas. Rev Bras Fisiol Exerc 2004; 3(1):120.

23. Heyward, Vivian H., and Dale R. Wagner. Applied body composition assessment. No. Ed. 2. Human Kinetics, 2004.

24. Buchheit $\mathrm{M}$ et al. Match Running Performance and Fitness in Youth Soccer. Int J Sports Med 2010;31 (11): 818 - 825.

25. Prado WLD, Botero JP, Guerra RLF, Rodrigues CL, Cuvello LCF, Dâmaso AR. Perfil antropométrico e ingestão de macronutrientes em atletas profissionais brasileiros de futebol, de acordo com suas posições. Rev Bras Med Esporte 2006; 2(12):61-65.

26. Benounis $\mathrm{O}$, Benabderrahman A, Chamari K, et al. Association of short-passing ability with athletic performances in youth soccer players. Asian J Sports Med 2013;4(1):41-48.

27. Le Gall F, Carling C, Williams, M, \& Reilly, T. Anthropometric and fitness characteristics of international, professional and amateur male graduate soccer players from an elite youth academy. J Sports Sci Med 2010; 13(1): 90-95.

28. Keogh JWL, Weber CL, Dalton CT. Evaluation of anthropometric, physiological, and skill-related tests for talent identification in female field hockey. Appl Physiol Nutr Metab 2003; 28(3): 397-409.

29. Dellagrana RA, Camargo Smolarek A, LaatEF, Campos W. Estado nutricional e desempenho motor de crianças praticantes de handebol. Fit Perform 2010; 9(1): $72-77$.

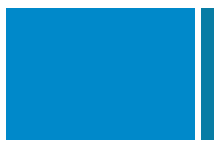

Corresponding author

Daniela Zanini

Nereu Ramos Avenue 1258-D, apart. 101, Chapecó-SC, zip code: 89813-000, Brazil.

Email: daniela.zanini@unoesc.edu.br 